\title{
Pemuda dan Resistensi: Sebuah Refleksi Kritis
}

\author{
Oki Rahadianto Sutopo \\ Youth Studies Centre \\ FISIPOL UGM \\ email: oki.rahadianto@ugm.ac.id
}

\begin{abstract}
Pemuda bukanlah sebuah entitas yang tunggal, bermakna tetap dan objek yang 'harus' ditaklukkan. Sebagai konstruksi sosial, pemuda akan selalu dalam proses "becoming" atau menjadi; dengan kata lain, sebagai subyek yang senantiasa harus bernegosiasi dengan kondisi sui generis berupa relasi kuasa yang tidak seimbang baik itu termanifestasi dalam institusiinstitusi yang merepresentasikan Negara, pasar, budaya maupun masyarakat itu sendiri. Relasi kuasa yang tidak seimbang tersebut terbentang baik dalam level lokal, nasional maupun global. Kesadaran akan posisi ontologis pemuda sebagai subjek yang selalu dalam proses "becoming" penting diletakkan sebagai landasan dalam memahami dinamika pemuda kontemporer.

Secara historis, pemuda sebagai konstruksi sosial tidak terlepas dari konteks sosio-kultural yang melingkupinya. Dalam tradisi AngloSaxon misalnya, Wyn (2016) menjelaskan bahwa pemuda muncul sebagai kategori yang baru dalam masyarakat sebagai respon terhadap perubahan sosial yang dimotori oleh kapitalisme, industrialisasi, dan urbanisasi. Pemuda muncul sebagai sebuah kategori baru guna merespon
\end{abstract}

kebutuhan akan tenaga kerja supaya roda akumulasi profit dan industrialisasi berjalan dengan mulus. Sebagai sebuah kategori baru dalam masyarakat, pemuda pada waktu itu sempat dikonstruksikan masuk dalam kategori menyimpang tidak hanya karena posisinya yang tidak lagi anak-anak dan, di sisi lain, belum cukup dikatakan dewasa, namun juga karena praktek budaya yang mereka ciptakan seringkali membuat Negara, pasar maupun generasi tua mengalami "moral panic". Dalam kajian budaya kaum muda (youth culture), kelompok-kelompok subculture seringkali menjadi sasaran kecamankecaman pada waktu itu. Secara politik, kelompok-kelompok subculture ini juga dianggap subversive dan cenderung resisten terhadap budaya dominan baik yang termanifestasi dalam gerakan sosial maupun gaya hidup mereka dalam kehidupan sehari-hari (Blackman, 2014).

Di sisi yang lain, pemuda sebagai konstruksi sosial juga tidak terlepas dari keniscayaan bertumbuh dan bertransisi baik secara biologis, psikologis maupun sosial. Dalam kajian transisi kaum muda (youth transition), pertama, pemuda dikonstruksikan akan mengalami transisi 
menuju kedewasaan (adulthood) dan kedua, secara kultural, implikasinya proses transisi tersebut juga melibatkan keberadaan institusi-institusi dominan yang ada dalam masyarakat, yaitu keluarga, pendidikan dan kerja. Dalam proses menjadi dewasa, pemuda secara deterministik dikonstruksikan akan melewati tiga fase yaitu: transisi menuju pernikahan, transisi menuju berumah sendiri dan transisi dari pendidikan menuju dunia kerja (Woodman and Wyn, 2015). Kedua proses menjadi dewasa ini saling bertautan satu sama lain dan pada perkembangannya seringkali tidak berjalan secara linear sebagaimana diharapkan. Dengan kata lain, dalam fase inipun pemuda harus secara aktif bernegosiasi terus menerus.

Kedua wajah yang saling berhimpitan yaitu budaya kaum muda (youth culture) dan transisi pemuda (youth transition) ini menjadi realitas kompleks yang harus dinegosiasikan oleh pemuda dalam kehidupan sehari-hari. Dalam kedua domain inilah pemuda dikonstruksikan oleh institusi-institusi eksternal di luar dirinya sekaligus secara aktif, sebagai agensi, melakukan resistensi terhadap pihak-pihak yang mencoba mengontrol dan melakukan klaim secara sewenang-wenang mengenai betapa 'toxic'-nya pemuda. Dalam kajian kepemudaan, kedua domain ini acapkali dikonstruksikan sebagai entitas yang terpisah. Namun dalam kenyataan empiris, kedua domain ini tidak bisa dipisahkan satu sama lain.

Dalam realitasnya, unsur politik dan resistensi ini termanifestasi menjadi dua aspek yaitu dalam bentuk gerakan sosial maupun politik kehidupan sehari-hari. Dalam konteks sosiologi generasi, Karl Mannheim dalam essay-nya "The Problem of Generations' (1952) menjelaskan mengenai potensi konflik antar-generasi. Bagi Mannheim, konteks sosial dan historis membentuk nilai, kepercayaan dan pandangan hidup setiap generasi dan hal ini seringkali tidak begitu saja dapat dengan mudah ditransfer kepada generasi berikutnya. Setiap generasi juga akan selalu bernegosiasi dengan perubahan sosial dimana nilai-nilai yang lama seringkali kurang relevan dalam konteks kontemporer. Kedua hal ini membentuk kesadaran yang berbeda antar generasi sehingga konflik generasi seringkali muncul. Mannheim menjelaskan bahwa ada kemungkinan konflik ini bertranformasi menjadi dorongan politik (political force) serta gerakan sosial yang melintasi kelas sosial dan menjadi agen bagi terciptanya perubahan sosial dalam masyarakat.

Selain resistensi yang termanifestasi menjadi gerakan sosial, bentuk resistensi yang dilakukan oleh kaum muda juga termanifestasi dalam gaya hidup. Kajian budaya kaum muda (youth culture) yang dekat dengan mahzab Birmingham telah banyak melakukan kajian dan eksplorasi mengenai subjek ini misalnya terkait dengan subkultur punk, mods, teds, skinheads, goths dll. Meskipun proponen dari kajian budaya kaum muda ini bervariasi dalam fokusnya namun dapat dijelaskan bahwa kelas sosial pemuda menjadi faktor penting bentuk resistensi ini. Subkultur pemuda yang berasal dari kelas pekerja (working class) dan termanifestasi menjadi symbolic resistance dipercayai dapat menjadi jawaban kultural, respon dan solusi kreatif bagi kaum muda dalam melakukan resistensi terhadap budaya dominan (Jensen, 2017). Dalam prosesnya, bentuk resistensi melalui subkultur pemuda ini dianggap tidak mampu mengubah struktur kuasa serta ekonomi yang timpang dan hanya memecahkan masalah secara imajiner 
(Sutopo dan Minza, 2014). Kajian subkultur ini pada perkembangannya mendapatkan banyak kritik antara lain dikarenakan fokus kajian yang bias gender, didominasi oleh subkultur pemuda kulit putih dan cenderung lebih merepresentasikan ekspektasi/posisi teoritis penulisnya daripada pelaku subkultur itu sendiri. Tidak hanya itu, Bennett (2011) misalnya juga menjelaskan bahwa dalam era modernitas lanjut, budaya kaum muda lebih mencerminkan fenomena post-subkultur dimana kelas sosial tidak lagi menjadi dasar pilihan gaya hidup dan subkultur tidak serta merta mengindikasikan resistensi terhadap budaya dominan. Kaum muda justru secara cair dan flexible berpindah-pindah dari subkultur satu ke subkultur yang lain tanpa keterikatan yang mendalam.

Dalam arus perubahan sosial yang berlangsung cepat dan massif, resistensi politik pemuda seringkali tergerus oleh kepentingan pragmatis, hasrat konsumsi dan juga upaya untuk "bertahan hidup". Kecenderungan ini jamak muncul dalam berbagai macam fenomena pemuda kontemporer; dalam kajian transisi pemuda konvensional misalnya, terkait dengan tuntutan bagi pemuda untuk menjadi dewasa secara sukses (succesful transition to adulthood). Pemuda dituntut untuk mempunyai pekerjaan, menikah dan menempati rumahnya sendiri dalam jangka waktu tertentu. Jika hal ini tidak terpenuhi maka transisi pemuda dianggap extended dan sangat mungkin didefinisikan sebagai gagal. Di sisi yang lain, perubahan sosial menuju era modernitas lanjut dan juga era hegemoni neoliberalisme membuat proses negosiasi dalam transisi pemuda menjadi semakin kompleks, rapuh dan rentan terhadap resiko-resiko yang tidak dapat diprediksi baik di masa sekarang maupun di masa depan. Yang semakin sering terjadi sekarang adalah pemuda harus memperpanjang masa transisinya di domain pendidikan dengan harapan dapat memperoleh pekerjaan yang layak; namun realitasnya, pendidikan tinggi juga tidak menjadi jaminan untuk mendapatkan pekerjaan. Jika beruntung mendapatkan pekerjaan pun, pemuda masih harus dihadapkan dengan gaji yang rendah, kontrak yang tidak jelas dan tidak adanya jaminan sosial. Mendapatkan pekerjaan juga tidak kemudian menjadi jaminan bagi pemuda untuk dapat membeli rumah sendiri dikarenakan pesatnya harga rumah tidak sesuai dengan naiknya gaji mereka. Jika beruntung dapat membeli rumah maka pemuda harus menyerahkan dirinya terperangkap dalam kerja bertahun-tahun guna membayar cicilan angsuran rumah. Dalam kondisi terhimpit seperti ini, pemuda perlahan-lahan tidak lagi menjadi political agents namun justru bergeser menjadi apa yang dinamakan oleh Peter Kelly (2006) sebagai entrepreneurial self. Dengan kondisi struktural yang menekan tersebut, resistensi politik pemuda sangat mungkin terkikis oleh kepentingan pragmatis dan kebutuhan "bertahan hidup".

Tidak hanya tekanan struktural sebagai implikasi dari hegemoni neoliberalisme dan era modernitas lanjut, resistensi politik pemuda juga semakin perlahan terkikis digantikan oleh hasrat konsumsi sebagai ritual perayaan tidak hanya terkait dengan identitas sosial namun juga perayaan akan "kemenangan" ideologi kapitalisme dan (sekarang ini) neoliberalisme itu sendiri. Dalam kajian budaya pemuda, terdapat dua pandangan yang berbeda mengenai hal ini. Pertama, para akademisi yang melihat bahwa tidak ada yang salah dengan tindakan konsumtif pemuda dan justru melihat bahwa ada potensi munculnya resistensi politik melalui 
elemen konsumsi tersebut. Kedua, para akademisi yang melihat bahwa tidak ada potensi resistensi politik dalam tindakan konsumsi. Sebagai konsumen, pemuda dikonstruksikan hanya menjadi objek yang taat membeli dan mengikuti segala macam komoditas yang ditawarkan oleh kapitalisme. Dalam konteks empiris tertentu, posisi penulis lebih menyepakati opsi kedua dimana seringkali pemuda hanya menjadi objek konsumsi dan kecenderungan resistensi politis justru terkikis oleh dominasi hasrat konsumsi tersebut. Dalam kehidupan sehari-hari, seringkali ditengahtengah kesenjangan sosial yang secara objektif semakin tajam, politisi korup yang dapat bertindak sewenang-wenang, ancaman perang nuklir maupun bahaya pemanasan global yang semakin nyata tidak serta merta menggerakkan sebagian pemuda untuk melakukan resistensi politik yang berarti guna memerangi berbagai macam isu-isu tersebut.

Sebagai sebuah refleksi kritis, lalu apa yang bisa ditawarkan penulis untuk berkontribusi dalam memunculkan kembali resistensi politik pemuda? Pertama, perlunya menumbuhkan kesadaran kritis akan adanya hegemoni dan dominasi neoliberalisme serta semakin melebarnya kesenjangan sosial menjadi agenda utama yang penting untuk disosialisasikan kepada para pemuda kontemporer. Kesadaran kritis akan membuat pemuda menyadari bahwa apa yang terjadi sekarang ini tidaklah bersifat taken for granted dan dunia berjalan dengan baik-baik saja, namun pemuda harus menyadari bahwa mereka sekarang ini justru berada di posisi yang paling rentan dalam berbagai hal tidak hanya di masa sekarang namun juga di masa mendatang. Kedua, perlunya membangun jaringan antar pemuda yang kritis dan peduli terhadap isuisu ketidakadilan sosial baik dalam skala lokal, nasional maupun global. Dengan berjejaring maka akan ada pertukaran informasi dan ruang untuk saling belajar tidak hanya mengenai berbagai bentuk ketidakadilan sosial di berbagai tempat namun juga berbagi mengenai bagaimana bentuk resistensi politik yang telah dan akan dilakukan oleh pemuda dari berbagai belahan dunia yang berbeda. Ketiga, mewujudkan jaringan dan solidaritas antar pemuda kritis tersebut dalam bentuk gerakan sosial baik dalam level lokal, nasional, maupun global. Manifestasi dari gerakan sosial ini dapat mengambil titik masuk yang beragam, tidak hanya terkait isu-isu yang krusial berdasarkan konteks sosial kultural tertentu namun juga terkait dengan solusi-solusi yang ditawarkan. Secara temporal, gerakan sosial dapat dilakukan secara sporadis maupun terencana dan bersifat massal namun yang terpenting adalah gerakan sosial tersebut harus terus terjaga energi dan keberlanjutannya. Dengan gerakan sosial yang berlangsung secara berkelanjutan ini maka diharapkan api resistensi politik pemuda tidak akan padam dan semoga dalam tahap serta waktu tertentu dapat menciptakan perubahan sosial. Sebuah perubahan sosial ke arah kehidupan yang lebih baik yang dipelopori oleh pemuda!

$* * * * *$

\section{DAFTAR PUSTAKA}

Blackman, Shane. (2014). Subculture Theory: An Historical and Contemporary Assesment of the Concept for Understanding Deviance. Deviant Behavior 35(6): 496-512.

Bennett, Andy. (2011). The Post-subcultural Turn: Some Reflections 10 years on. 
Journal of Youth Studies 14(5): 493-

506.

Jensen, Sune Qvotrup. (2017). Towards a Neo Birminghamian Conception of Subculture? History, Challenges, and Future Potentials. Journal of Youth Studies 1-18 (online first).

Kelly, Peter. 2006. The Entrepreneurial Self and Youth at Risk: Exploring the Horizons of Identity in the Twenty First Century. Journal of Youth Studies 9(1): 17-32.

Mannheim, Karl. 1952. The Problem of Generations. In Karl Mannheim.

Essays On The Sociology of Knowledge. London: Routledge.

Sutopo, Oki Rahadianto \& Minza, Wenty Marina. 2014. Perspektif Budaya dalam Kajian Kepemudaan. In M. Najib Azca, Derajad. S Widhyharto and Oki Rahadianto Sutopo (Eds). Buku Panduan Studi Kepemudaan: Teori, Metodologi dan Isu-Isu Kontemporer.Yogyakarta: Youth Studies Centre FISIPOL UGM. 